\title{
Time Categorising Representation in Javanese Culture through Jampe-Jampe Patemon Manuscript
}

\author{
Leona Dwi Untari ${ }^{1}$, Murni Widyastuti ${ }^{2}$, Turita Indah Setyani ${ }^{3}$ \\ 1,2,3 Faculty of Humanity, University of Indonesia \\ 1leona.dwi@ui.ac.id, 2widyastuti_murni@yahoo.com, ${ }^{3}$ turita.indah@ui.ac.id
}

\begin{abstract}
One of the ancestral heritage that exists in the island of Java, yet can still be applied universally without perceiving race, religion nor other differences, is the usage of Primbon. The script titled Jampe-Jampe Patemon: Kalahiran will be used as an object of research as it encompasses the teachings and important advice concerning primbon and religiosity. Therefore, the purpose of this research is to reveal the time categories in general and specific way; in Jampejampe Patemon: Kalahiran manuscript with the Javanese religious values perspective, relating to primbon. This study uses qualitative method in comprehending the contents of the text and theory of representation by Stuart Hall. This research will be able to provide newfound knowledge and insight for the general public, specifically from the Javanese religious point of view. The results of the research conclude that the time zone in the Jampe-Jampe Patemon: Kalahiran manuscript is divided into 6 (six) parts. Those are laho-jahal, ngitarad, jiki, rih, ben, and ihrak. The conclusion of the research is that Javanese people still believe in primbon (including time primbon) that is still relevant and working by now, how it is important to have the ancestors' teachings and advice through analysing Jampe-Jampe Patemon text.
\end{abstract}

Keywords: Primbon; Jampe-Jampe Patemon; Time Categorising; Javanese; Religiousity.

\section{INTRODUCTION}

Religiosity is the most important thing in human life. The mutual acculturation between Islam and Javanese culture is clearly seen by accommodating each other's interests [1]. Javanese culture is not massively eroded due to the presence of Islam. Javanese culture provides a platform for Islamic religion to interact with filtrations based on the teachings of kejawen. So, the end result is Kejawen teachings with Islamic shades.

One of the Kejawen teachings with Islamic shades and being the most powerful thing that happened in the past is primbon. Javanese people is famous for its primbon passed through generations. However, 'outdated' mindset of primbon must be put aside so society will be able to benefit from newfound knowledge from this research. Javanese society is famous for its primbon which is hereditary inherited from ancestors to posterity. For examples are the birth primbon, weton (pon, pahing, legi, wage and kliwon) and so on,- while the primbon about the time laho-jahal, ngitarad, jiki, rih, ben, and ihrak are very rarely known by Javanese society especially by people now days. 
One of Javanese literary works resulting from written culture is the text. "The text is a concrete object that can be seen or held" [2]. This research uses a text in the Javanese script entitled Jampe-Jampe Patemon: Kalahiran (hereinafter referred to as JJP). JJP manuscript which became the collection of National Library of Indonesia is a copy of crumbling and undetected kropak (book made of palm leaves or also called lontar, especially in Java). It contains religious teachings that believed and used as guidance by Javanese-Muslim society in the past. In these teachings there are also a division of time that is unknown yet to the public universally.

The literature review on primbon is reviewed by Yulianti. This study aims to describe the state of Serat Primbon manuscripts accompanied by transliteration, text editing, making translations, describing the signs of death contained in Serat Primbon, and describing behavior towards death contained on Serat Primbon. This research was conducted using descriptive method with philological research methods. The data of this research are in the form of Serat Primbon text which contains information about the signs of death starting from three years before dying until one day before death and behavior towards death [3].

The research conducted by Yulianti looked at the signs that occur in humans near death. This is absolutely related to time. If we draw the line back further in fact to avoid bad things, which will happen to humans, we also need to learn good and bad days so as not to produce something that is not desirable. The time categorization in general is already exists in the common primbons that circulate in the palace community and its surroundings. In this study, novelty is present in the data source, namely the coastal primbon which will produce an unusual time categorization.

Until now, research or writing that specifically examines the religious elements contained in the JJP text has not been found. Therefore, this research is a breakthrough for Javanese literary works towards JJP manuscripts, especially contributing new information in a religious perspective and the time categorization that is not available on another previous research. This research can be interpreted and applied in life as a unifying nation. The 'outdated' mindset about the primbon must be set aside so that with this research people can gain benefit from new knowledge contributions.

Knowledge about time is not only limited to the days-nights, now-later, or now-tomorrow. Among the generally known times there seems to be more complex divisions of time that people must learn to contribute to new knowledge or even avoid undesirable things. By those description, this research problem is how's the time division of past Javanese society contained in the Jampe-Jampe Patemon text? According to the writer, that problem can be solved by using the theory of representation.

\section{METHOD}

Given that the text comes from a copy of kropak-kropak currently unknown to its existence, the researcher makes the manuscript as a single script / codex unicus. After all of the philology steps are done, it is used the analytical methods through Theory of Representative by Stuart Hall. Representation means using language to represent or to say something meaningful about the world meaningfully. According to Stuart Hall, it is an essential part of the process of production and exchange of meaning between members of a culture. [4] 
Sentence by sentence are highlighted carefully, finding data contained of time in Javanese. Interpretative reading is also used to find the real meaning or the background reason why or how the JJP text categorizes those time.

According to Patton quoted in the book "popular fiction: Theory and Methods Study", "No consensus exists about how to classify the varieties of qualitative research (there is no agreement on how to classify various types of qualitative research)" [5]. From this statement, it can be interpreted that this qualitative research could use any approach as long as the approach is justified in the study. [6]

Data were collected through in-depth literature study from JJP text and some support documents. Data that found in text are analyzed by the closets meaning from another correlative data from primbon which used regularly by now.

\section{RESULT AND DISCUSSION}

When it comes to time, Javanese society is famous for its Pancawara calendar.

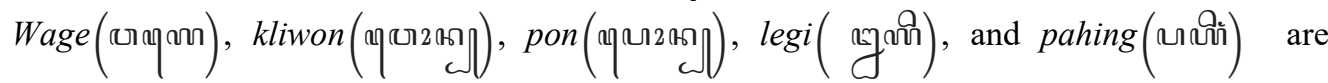
members of the Pancawara calendar which means one week consisting of five days, in Javanese culture. Besides, Japanese culture also has a date to determine the fortune of someone which is similar to Pancawara. This calendar system is called rokuyou (六 曜). In accordance with its name which is rooted from the kanji characters "六" (roku) means "six", rokuyou consists of six days, namely senshou (先勝), tomobiki (友引), senbu (先 負), butsumetsu (仏 滅), taian (大安) ), and shakkou (赤口). This Japanese calendar is totally different from Meiji's Era. When at Meiji's Era (1872 M) the government decide to move to masehi (Islamic) calendar. [7]

As a result, research has reported that in the discovery of the time division, different from the division of time in Java in general (Pancawara), according to Jampe-Jampe Patemon: Kalairan manuscript, time is divided into 6 time: laho or jahal, ngitarad, jiki, rih or marih, ben, and ihrak. This time used as sign and barrier by the Javanese people in the past, whether they wanted to war or just went selling something. This kind of time are rarely found in common Javanese society.

Laho-jahal is a time categorized as a bad time. As written in the text JJP, "Lamon dina Sabtu esuke, jahal arane ala sebarang gawe" means, the next Saturday (including) jahal means all work is bad (source: JJP page 2), so it is not recommended to practice or do things that are in good faith. That is, good value work should not be done at that time because in the end the result may be bad. According to Javanese dictionary, Laho-jahal comes from the word 'laha', means needy or poor. It is also mean 'barrier' (as a net that is used by fisherman across the sea). From that basic word, it shows us that 'laha' word itself has bad meaning. It is bad because Javanese people believe that people who lived inside the barrier will not be able to be freed. Javanese people in the past named an event or time as equivalent as its feature to warn their environment.

According to Kitab Primbon Betaljemur Adammakna, Saturday is known is dalaning pati- 'ways lead to death'. Javanese people's belief about balance in life is also shown when they categorized division of time. Saturday which followed by pon, one of the pasaran time of the Javanese time unit, is known as a bad time. There is no explanation about that statement, but Javanese people believed and tried to avoid that bad day when it comes to doing big 
activity, such as working, moving, or going to war. On the next level of badness, Saturday which followed by kliwon, another Javanese time unit, is labeled as worse time. Nothing can be done except staying at home, or doing activity that is too far from home. [8]

As captured from JJP, “... anging lunga perang rahayu waktu magerib, ngitarad. Abecik lunga aperang atawa akokona apa ya nyelina tur salamet”, means “...but (if you're) going to war at dusk (it's already including) ngitarad, Whether for battle or (used to) ordering (any) work is sure to arrive and survive. (source: JJP, page 2).

Ngitarad is a time that is categorized as a good time or has good properties. Bad work may end up being a good job. So at this time it is recommended to do various things. Ngitarad comes from the word 'tara', means days in between; good days to do 'tapa' (isolate oneself, meditate). Javanese people in the past named this time as that since they done research at first. They done the 'tapa' thing repeatedly to prove it then seen what just happened to their life.

Jiki is a good time when used for activities. Any work is permitted and blessed by God. "Kang aran waktu salih iku jiki, arane sakehe panggawe iku abecik". Jiki comes from the word 'jikik or jukuk', means taking something to bring; various things, get something good. As we know, God will give his blessing whenever, wherever we done something good in life. In this JJP text are also described as that. “...Lamon ala gawe aperang waktu jiki iku Allah menang." (source: JJP, 5) The so-called good time is jiki, meaning that all work is good, but bad for war. At that jiki God won. (source: JJP, page 5)

The time of rih / marih is a very bad time. Unfortunate things can happen at that time so it should not be used for anything this time. Rih/marih comes from the word 'mari' means finish; done; complete. 'Finish' in life means to 'die'. Javanese people in the past conclude that anything done in that time will conduce bad ending. As quoted from JJP page 39 "marih arane ala iku na'as" means, Marih means bad, that's unlucky.

Primbon Betaljemur Adammakna were also published about the provisions for going to war. Each day is having different bad times. Those bad times are called na'as, which must be avoided to avoid bad luck. Javanese people never told their descendants to be clever or to be rich. They always advised about having luckiness and safeness. Deep inside their minds, they believed that people who were born having luck and blessing will be safe no matter how the condition is. So, in order to make their descendants safe, they will avoid any bad time to do something such as work, move, and war.

Ben time is a bad time. This time should be avoided. Ben is one of 'dialect' that is very famous in East Java means 'let it be' or 'never mind' (something that shows abandon). We all know if doing things ended by abandon is vain and useless. In order to avoid doing meaningless thing and wasting time, Javanese people in the past warned their environment as that. "ana pon ing dina Jumuat awal ing waktu ben arane kira-kirane ebar pasar ihrak." Quoted from JJP page 6, means "as for the Friday, early morning is called ben, (and) approximately after noon (after the market closed) is bad (too).

Written down on Kitab Betaljemur Adammakna, on Friday those are two na'as time. Those are from 8 AM to 9 AM; and 1PM to 2PM. It's correlated that those different primbon are having the same idea and calculation about na'as day.

The last one is ihrak, it is a bad time. Categorized as a bad time because the position of time is considered 'sapit' or wedged. Ihrak comes from the word 'irat' means cut into pieces; tinny thorn; ripped. Javanese people in the past will never let their beloved people being cut into pieces, whether through their job, their life, including their heart. They will always give warning each other. The wedged position is also an explanation to be avoided because someone who lived in that position will not be able doing anything. 
"Kang kaping pat ihrak arane sapit, ala arane." means, the fourth name is ihrak, meaning people being pinched, it means bad. (source: JJP, page 6). The position of meaningful things are also calculated. Let's see how Chinese people talking about 'Feng Shui', whenever they try to build a house, or even just their talking position when they want to do presentation.

Feng shui (風水) is an ancient topography from China that believes how humans and heaven (astronomy), and earth (geography) can live in harmony to help improve life. "Don't choose a house or shop that is located in the middle, it will be heavy (abot mikul) and not shinny!" Based on the rules of feng shui, there is no such standard. Based on feng shui, the middle position is actually needed if the 'soil' energy is weak. So, if we talk about it from the feng shui angle, there is no assumption that the house located in the middle is not good because of mikul. If the smaller building is flanked by bigger and taller buildings, this is not feng shui-friendly, because it is categorized as "pinched". [9]

Primbon's authors are generally unknown. Most of the names posted on the title page or at the beginning of a primbon book are generally collector of them. The content of primbon is a variety of knowledge related to daily needs for the purpose of obtaining salvation [10].

Broadly speaking the primbon contains problems related to birth, marriage, death, and as something related to human relationships with nature [11], including about the disease and its treatment. Therefore, in the primbon were found instructions for getting health with medication and recipes.

The ancestors of the Javanese believe that the 'sign' has a great influence in everything, from health, fortune, misfortune and influence to human nature, and the way of human life. Some opinions claim primbon is an ancestral heritage that has nothing to do with religion, pure cultural heritage so it can run side to side with anything, anywhere and anytime.

Return to the 'time' realm, there is a group called Extreme Realism, which states that time is a universal absolute autonomous reality, has no intrinsic unity, but only shows pure sequences. This spiritual view developed among ancient Indian philosophers such as the Jaina, Nyaya and Vaiseshika around 500 BC. They claim that time is the real nonmaterial substance. The substance of unitary-ism is limited, eternal, non-existent and undivided. At that time only one was accommodating and absorbing everything. In addition there is an empirical time that allows for changes. Empirical time by human conventions is laid on that real time. This view was shared by ancient Indonesian people, where primbon appeared. [12]

The religion is the most valuable human possession. In this case, it can be said that religion is one aspect that distinguishes human from animals and other aspects of culture. Religion is an authoritative power and has the ability to shape society and culture. Society and culture is also a container in the formation of religion.

Religion comes from the word re eligere or religare. Re-eligere means to do things thoroughly repeatedly, while religare means to re-establish or unite. Religion relates to the personal bizarre and occult things. This certainly causes the truth about things that contain religious elements is difficult to define. Religion is generally given by God through revelation. Global religiousness, religious motivation, and religious coping might positively or negatively influence affects, cognitions, and behaviors. Specifically, it appeared that global religiousness, intrinsic religious motivation, and positive religious coping might be related to adaptive psychological implications, while extrinsic religious motivation and negative religious coping might be related or unrelated to maladaptive psychological implications. [13]

Religion is generally used as a benchmark in the role of religion, its influence for society, its relation with ethics or morality. In this respect, the most prominent and important aspect is religion in the role of religion or in seeking salvation. 
One way to pursue safety is to pay attention to time. Time is considered to have its properties respectively, so that the properties need to be understood and made an activity can run as desired. The ancestors of the Javanese people believed in the power of the Almighty beyond the power of man himself. The power is capable of mastering the fate of human life. This fate can be determined by the day of birth, the day of marriage, the day of building a house, or the day at the start of an activity. Any fate is marked and recorded. In ancient times, that noted it is the parents who always pay attention to the signs of an event and its impact. It is often called "niteni". This niteni work is based on maca ing waskitha, which means reading events from phenomena or signs (nature) that have occurred as a guide to understanding every event that will happen next. These memories are then recorded as people begin to recognize writing. Records of natural phenomena whose patterns have been tested repeatedly empirically, then arranged into a dating system. Records that are believed to have been verified are then recorded, titled primbon. For example in the calculation of marriage. Both city and village families use calculations based on date of birth to determine when the wedding is done. It has also been described clearly by H.A. van Hien. [14]

As the above explanation, these six categories of time are more or less just dividing the time into two big parts of good and bad. The level of good and bad is not clearly visible. It's just that this division of time is considered important by the people of the past to give birth to this primbon text. In addition, it can be expected that all work and deeds need to be considered with due regard to good times and bad times so that the end result does not deviate from the initial intentions of a job or activity.

Time that falls into a good category is referred to "sangat / sa'at" time in Javanese terms. According to the tradition that is still practiced by the Javanese people, sangat time is divided into 3. The first is Sangat Rasul based on the great apostolic event; Sangat Agung that is a good time to plan (marriage, circumcision, proposal, etc.), negotiate and dialogue; and Sangat Urip is a good time to travel, work, war or just leaving the house. Whereas time which is included in the bad category is called "na'as / nahas" time in Javanese terms. [8]

Reference to previous research is that the background of time is considered to have caused the occurrence of human safety cases in the past so to avoid obstacles it is necessary to consider the right time. Thus, if the reader believes and applies these thoughts in daily life, it is believed to be able to avoid accidents or unexpected things [15].

\section{CONCLUSION}

The reader can understand that in addition to the primbon days, dates, months and years it turns out that the Javanese past also studied and applied the time primbon (which is shorter than the day). According to JJP text, time is divided into 6 time: laho or jahal, ngitarad, jiki, rih or marih, ben, and ihrak. This time used as sign and barrier by the Javanese people in the past. Therefore, this time division is important to be studied by the society today, in addition to preserving the ancestral heritage, the community can also apply it as a consideration in doing an activity. Since the Jampe-Jampe Patemon text is older than 1 century, the text's content cannot be perfectly conveyed because of the corruption of the text (the text copier cannot read the original text or the passage because of the broken part). The time category as mentioned earlier is absolutely related to the harmony of life which includes the concept of balance, the concept of order, and the concept of harmony for Javanese society. By exploring the categorization of time in the text, this research contributes to new knowledge for the public so that it can inspire future societies to do more of this kind of research which is still relatable by now. 


\section{REFERENCES}

[1] Ridwan, "Mitisme Simbolik dalam Tradisi Islam Jawa" IBDA vol.6, P3M STAIN Purwokerto, 2008.

[2] Baried, S.B., "Pengantar Ilmu Filologi" Jakarta: Pusat Pembinaan dan Pengembangan Bahasa Departemen Pendidikan dan Kebudayaan, 2011.

[3] Yulianti, “Tinjauan Filologi dan Isi Serat Primbon” B.A. dissertation, Universitas Negri Yogyakarta, Yogyakarta, 2012.

[4] Hall, S., “Representation:Cultural Representation and Signifying Practices”. London: SAGE, 1995.

[5] Adi, I.R., “Fiksi Populer: Teori dan Metode Kajian”. Yogyakarta: Pustaka Pelajar, 2011.

[6] Tamaraw, J. “Analisis Sosiologi Sastra Terhadap Novel 5 Cm” Indonesian Literature of Sam Ratulangi University, 2015.

[7] Abdurakhman, H. “Uchi dan Soto”. Jakarta: PT. Gramedia, 2019.

[8] Tjakraningrat, K.P.H, “Kitab Betaljemur Adammakna” Yogyakarta: CV. Buana Raya, 1994

[9] Lim, Suhana. “Feng Shui: Mitos dan Fakta” Jakarta: Gramedia Pustaka Utama, 2017.

[10] Sutrisno, E.T., "Primbon Djawi Adji Wara” Surakarta: Mas, 1961.

[11] Subali, D., "Primbon dalam Kehidupan Masyarakat Jawa (Unsur Sastra Mitologi, Takhayul dan Sejarahnya)”. Yogyakarta: Direktorat Jendral Kebudayaan, Departemen Pendidikan dan Kebudayaan, 1985.

[12] Yusuf, B.A., "Konsep Ruang dan Waktu dalam Primbon serta Aplikasinya pada Masyarakat Jawa”. Comparative Religion of UIN Syarif Hidayatullah Jakarta, 2009.

[13] Briki, W., Aloui, A., Bragazzi, N.L., Chaouachi, A., Patrick, T., and Chamari, K. "Trait Self-Control, Identified-Introjected Religiosity and Health-Related-Feelings in Healthy Muslims: A Structural Equation Model Analysis” Journal Plos, 2015.

[14] H. A. van der Hien, "De Javaansche Geestenwereld en de Betrekking: die Tusschen de Geesten en de Zinnelijke wereld Bestaat, Verduidelijkt door Petangan's of Tellingen bij de Javanen in Gebruik" Semarang: G.C.T. Van Dorp \& co, 1896.

[15] K. Saddhono, "Cultural and Social Change of Foreign Students in Indonesia: The Influence of Javanese Culture in Teaching Indonesian to Speakers of Other Languages (TISOL)," in IOP Conference Series: Earth and Environmental Science, 2018, vol. 126, no. 1 . 